\title{
Efektifitas Iklan Pada Keputusan Nasabah BPRS Di Madura
}

\author{
Rudy Haryanto \\ Fakultas Ekonomi dan Bisnis Islam IAIN Madura \\ Email: rudyharyanto76@yahoo.co.id
}

\begin{abstract}
Abstrak:
The tight competition between Islamic financial institutions, BPRS in Madura seeks to maintain its existence. Acceleration of the program to increase capacity to be more competitive in developing its business is absolutely necessary in order to maintain business continuity, one of which is through the optimization of the marketing sector. Advertisements are promotional facilities used by BPRS to inform everything about their products. To optimize the function of advertising, the information provided must include product benefits, product prices and product benefits compared to competitors. For this reason, the analysis of this research uses the AIDA concept, namely Attention, Interest, Desire and Action. This study aims to determine the effectiveness of advertising by using the AIDA concept on the decision to become a customer of a BPRS in Madura. The results of the study show that AIDA simultaneously has a significant effect on the decisions of the customers of BPRS in Madura. This is evidenced by the coefficient of determination of AIDA's ability to explain its influence on the decision to become a customer of a BPRS in Madura by $82.4 \%$ and $17.6 \%$ explained by other variables not examined. While partially AIDA significantly influences the decision to become a customer of a BPRS in Madura with a significance level of $2.4 \%, 1.4 \%, 0.08 \%$ and $0.02 \%$, respectively. Based on these facts, the most dominant AIDA concept influencing the decision to become a customer of a BPRS in Madura is the Action substance with a significant value of $0.02 \%$.
\end{abstract}

[Ketatnya persaingan antar lembaga keuangan syariah, BPRS Di Madura berusaha mempertahankan eksistensinya. Akselerasi program peningkatan kemampuan untuk lebih kompetitif dalam mengembangkan bisnisnya mutlak diperlukan agar bisa mempertahankan keberlangsungan usaha, salah satunya melalui optimalisasi sektor marketing. Iklan adalah sarana sarana promosi yang digunakan oleh BPRS guna menginformasikan segala sesuatu produknya. Guna mengoptimalkan fungsi iklan, informasi yang diberikan harus mencakup manfaat produk, harga produk serta keuntungan-keuntungan produk dibandingkan dengan pesaing. Untuk itu analisis iklan dalam penelitian ini menggunakan konsep AIDA yaitu Attention, Interest, Desire dan Action. Penelitian ini bertujuan untuk mengetahui efektifitas iklan dengan menggunakan konsep AIDA pada keputusan menjadi nasabah BPRS di Madura. Hasil penelitian menunjukan bahwa secara simultan AIDA berpengaruh secara siknifikan terhadap keputusan nasabah BPRS di Madura. Hal ini di buktikan berdasarkan koefisien determinasi kemampuan AIDA menjelaskan pengaruhnya terhadap keputusan menjadi nasabah BPRS di Madura sebesar 82,4\% dan 17,6 \% dijelaskan oleh variabel lain yang tidak diteliti. Sedangkan secara parsial AIDA berpengaruh secara siknifikan juga terhadap keputusan menjadi nasabah BPRS di Madura dengan tingkat siknifikansi masing-masing 2,4 $\%, 1,4 \%, 0,08 \%$ dan 0,02\%. Berdasarkan fakta tersebut konsep AIDA yang paling dominan mempengaruhi keputusan menjadi nasabah BPRS di Madura adalah subtansi Action dengan nilai siknifikan $0,02 \%$.]

Kata Kunci: Iklan; Konsep AIDA; Keputusan Nasabah. 


\section{PENDAHULUAN}

Dewasa ini, perkembangan ekonomi Islam sangat pesat ditandai dengan banyaknya lembaga-lembaga keuangan berbasis syariah atau Islam. Lembaga keuangan syariah adalah suatu bentuk dari wujud permintaan pasar di Indonesia akan hadirnya suatu sistem perbankan yang halal (memenuhi prinsip syariah). Sampai saat ini tercatat sebanyak 199 bank syariah yang terdiri dari 12 Bank Umum Syariah (BUS), 22 Unit Usaha Syariah (UUS) dan 165 Bank Pembiayaan Rakyat Syariah (BPRS). ${ }^{1}$ Kondisi ini menunjukan indikasi positif bahwa ekonomi Islam dapat diterima dengan baik oleh masyarakat Indonesia.

Lembaga keuangan syariah juga terus mewabah di perkotaan hingga di pedesaan, baik berupa bank pemerintah yang berskala besar maupun bank swasta yang berskala kecil. Menurut Muhammad, operasionalisasi bank syariah dirasa kurang menjangkau usaha masyarakat kecil dan menengah. Ketidakmampuan lembaga ini menjadi penyebab terjadinya kekosongan pada segmen pasar keuangan di wilayah pedesaan. Untuk menanggulangi kejadian ini, perlu adanya suatu lembaga yang menjadi jalan tengah. Muncul usaha untuk mendirikan bank dan lembaga keuangan syariah mikro, seperti Bank Pembiayaan Rakyat Syariah (BPRS) dan Baitul Maal Wat Tamwil (BMT) yang bertujuan untuk mengatasi hambatan operasional daerah. ${ }^{2}$

Bank Pembiayaan Rakyat (BPR) adalah salah satu jenis bank yang diizinkan beroperasi dengan sistem syariah di Indonesia yang banyak dikenal dengan sebutan Bank Pembiayaan Rakyat Syariah (BPRS). Aturan hukum mengenai BPRS mengacu kepada UndangUndang Nomor 10 tahun 1998 dan Peraturan Bank Indonesia (PBI). Dalam sistem perbankan nasional, BPRS adalah bank yang didirikan untuk melayani Usaha Mikro dan Kecil (UMK). Sektor UMK ini yang menjadikan BPRS berbeda pangsa pasarnya dengan Bank Umum/Bank Umum Syariah. Dalam sistem perbankan syariah, BPRS merupakan salah satu bentuk bank yang pengelolaannya harus berdasarkan prinsip syariah. ${ }^{3}$

Bank Pembiayaan Rakyat Syari'ah (BPRS) Di Madura ada tiga yaitu BPRS Bhakti Sumekar yang berkantor pusat di Kabupaten Sumenep, BPRS Sarana Prima Mandiri yang berkantor pusat di Kabupaten Pamekasan, dan BPRS Bhakti Artha Sejahtera yang berkantor pusat di Kabupaten Sampang. Data jumlah nasabah BPRS di Madura tesebut dalam lima tahun terakhir terus mengalami peningkatan, peningktan yang fenomenal terjadi di BPRS Bhakti Sumekar dengan berturut-turut menjadi BPRS terbaik kedua tungkat nasional, dan terbaik petema di Jawa Timur. ${ }^{4}$

Ketatnya persaingan antar lembaga keuangan syariah, BPRS Di Madura berusaha mempertahankan eksistensinya di masyarakat. Oleh karena itu, peningkatan kemampuan untuk lebih kompetitif dalam mengembangkan bisnisnya mutlak diperlukan agar bisa mempertahankan keberlangsungan usaha, salah satunya melalui marketing. "Marketing (pemasaran) diartikan sebagai proses sosial dan manajerial di mana individu dan kelompok mendapatkan kebutuhan dan keinginan mereka dengan menciptakan, menawarkan kebutuhan dan bertukar sesuatu yang bernilai satu sama lain". ${ }^{5}$

Pentingnya pemasaran dilakukan dalam rangka memenuhi kebutuhan dan keinginan masyarakat akan suatu produk dan jasa. Pemasaran menjadi semakin penting dengan semakin meningkatnya pengetahuan masyarakat. Pemasaran juga bisa dilakukan dalam rangka menghadapi pesaing dari waktu ke waktu yang semakin meningkat. Para pesaing jusru semakin gencar melakukan usaha pemasaran dalam rangka memasarkan produknya.

\footnotetext{
1 http://www.ojk.go.id (diakses pada tanggal 7 Januari 2017).

2 Muhammad, Manajemen Bank Syariah, Yogyakarta: Sekolah Tinggi Ilmu Manajemen YKPN, 2011, 18.

3 https://id.wikipedia.org/wiki/BPRS Bhakti_Sumekar (diakses pada tanggal 03 Juli 2016).

4 http://www.ojk.go.id

${ }^{5}$ Kasmir, Studi Kelayakan Bisnis, Jakarta: Kencana, 2003, 47.
} 
Hal tersebut tidak terlepas dari yang dilakukan oleh lembaga keuangan atau perbankan yang tujuannya adalah untuk memaksimumkan pelayanan terhadap pelanggan melalui berbagai pelayanan yang diinginkan oleh nasabah. ${ }^{6}$

Perkembangan dan kinerja perbankan syariah saat ini terus berkembang, namun proses sosialisasi pada masyarakat harus tetap gencar dilakukan. Ditambah lagi dengan semakin banyaknya produk-produk perbankan syariah yang mulai ditawarkan kepada masyarkat. Salah satu cara yang paling sering digunakan dan ampuh bagi lembaga keuangan/perbankan adalah dengan memasang iklan baik di media cetak atau televisi.

Iklan adalah sarana promosi yang digunakan oleh Bank guna menginformasikan segala sesuatu produk yang dihasilkan oleh Bank. Informasi yang diberikan adalah manfaat produk, harga produk serta keuntungan-keuntungan produk dibandingkan dengan pesaing. Tujuan iklan adalah berusaha untuk menarik, dan mempengaruhi calon nasabah. ${ }^{7}$ Periklanan sering menjadi sarana promosi strategis yang mampu menjangkau nasabah secara luas dan juga memerlukan biaya yang lumayan besar.

Dalam menghasilkan iklan yang baik, selain memperhatikan struktur iklan diperlukan juga konsep "AIDA". Attention (perhatian) berarti bahwa iklan harus mampu menarik perhatian khalayak sasaran. Untuk itu iklan harus mampu membuat kata atau gambar yang powerfull yang bisa menarik perhatian hingga orang memperhatikan isi pesan berikutnya. Interest (tertarik) bagimana nasabah berminat dan memiliki keinginan lebih jauh. Iklan harus mengandung daya tarik bagi nasabah sehingga informasi yang diberikan mengandung minat bagi calon nasabah. Desire (hasrat) iklan harus mampu menggerakan keinginan orang untuk memiliki atau menikmati produk tersebut. Iklan harus mampu menciptakan kebutuhan calon pembeli. Kemudian action (tindakan) mengandung arti bahwa iklan harus mampu memiliki daya membujuk calon pembeli agar sesegera mungkin melakukan suatu tindakan pembelian. ${ }^{8}$

Tujuan akhir dari beberapa promosi adalah untuk membuat seseorang dapat menggunakan sebuah produk ataupun jasa yang ditawarkan. Untuk itu terdapat model klasik yang dapat digunakan utuk menjangkau tujuan promosi tersebut yakni konsep "AIDA". AIDA sendiri merupakan singkatan dari perhatian (Attention) minat (Interest) keinginan (Desire) tindakan (Action) dimana konsep ini merupakan tahapan keterlibatan nasabah dengan suatu pesan promosi. ${ }^{9}$

Dalam pembuatan iklan, untuk menghasilkan iklan yang baik penting juga menggunakan elemen-elemen dalam sebuah rumus yang dikenal AIDA. Yang terdiri dari:10 1) Perhatian (Attention); 2) Tertarik (Interest); 3) Minat (Desire); dan 4) Tindakan (Action).

AMA (American Marketing Association) mendefinisikan "perilaku nasabah merupakan interaksi yang dinamis antara kognisi, afeksi, perilaku dan lingkungannya dimana manusia melakukan kegiatan pertukaran dalam hidup mereka".11

Perilaku nasabah atau pembeli berkaitan dengan proses pemilihan produk yang akan dibeli yang terdapat dalam proses pembelian. Proses pembelian perlu dipelajari untuk mengetahui mengapa sesorang memilih dan membeli serta lebih senang dengan produk merek tertentu. ${ }^{12}$

\footnotetext{
${ }^{6}$ Kasmir, Pemasaran Bank, Jakarta: Kencana, 2004, 57.

7 Ibid., 156.

8 Diah Syafita Johar "Pengaruh AIDA (Attention, Interest, Desire, Action) terhadap Efektifitas Iklan online (JAB/Vol. 26 NO. 1 September 2015).

${ }_{9}^{9}$ P R Smith, Great Answers to Tough Marketings Questions, Jakarta: Penerbit Erlangga, 2001, 65.

10 Sentot Imam Wahjono, Manajemen Pemasaran Bank, Surabaya: Graha Ilmu, 2009, 134.

${ }^{11}$ Supranto, Nandan Limakrisna, Perilaku Konsumen \& Strategi Pemasaran, Jakarta: Mira Wacana Media, 2011, 3.

12 Sojan Assauri, Manajemen Pemasaran, Jakarta: RajaGrafindo, 2013, 132.
} 
Teori perilaku nasabah yang dibangun atas dasar syariat Islam, memiliki perbedaan mendasar dengan teori konvensional. Perbedaan ini menyangkut nilai dasar yang menjadi fondasi teori, motif dan tujuan konsumsi, hingga teknik pilihan dan alokasi anggaran untuk berkonsumsi. Tiga nilai dasar tersebut terdiri dari:13 1) Keyakinan adanya hari kiamat dan kehidupan akhirat; 2) Kesuksesan diukur dengan moral bukan banyaknya kekayaan; dan 3) Kedudukan harta merupakan anugerah Allah SWT.

Perusahaan yang cerdas berusaha untuk memahami proses keputusan pembelian nasabah secara penuh mulai dari pengalaman dalam pembelajaran, memilih, menggunakan, dan bahkan menyingkirkan produk. Proses keputusan pembelian nasabah terdiri atas lima tahap yang dapat digambarkan sebagai berikut:14 1) Pengenalan Masalah; 2) Pencarian Informasi; 3) Evaluasi Alternatif; 4) Keputusan Pembelian; dan 5) Perilaku Pasca Pembelian.

Penelitian tentang pengaruh iklan telah banyak dilakukan, diantaranya yang dilakukan oleh Jefri Heridiansyah dengan judul Pengaruh Advertising terhadap pembentukan Brand Awareness serta dampaknya pada keputusan pembelian produk kecap pedas ABC (studi kasus pada nasabah pengguna kecap pedas di kota semarang). Hasil dari penelitian ini menunjukkan bahwa variabel bebas advertising dan brand awareness secara simultan mempunyai pengaruh positif dan signifikan terhadap keputusan pembelian kecap pedas ABC. ${ }^{15}$ Penelitian dengan tema yang sama dilakukan oleh Nielsen Djuwandono Hermawan dengan judul Efektivitas Iklan Televisi Tokobagus.com versi "mau jual mobil?" pada masyarakat Surabaya. Hasil dari pnelitian ini menunjukan bahwa iklan Tokobagus.com termasuk sebagai iklan yang efektif. Tingkat efektivitas iklan tersebut diperoleh dari hasil penelitian menggunakan Direct Rating Method dan termasuk dalam kategori iklan baik dengan nilai DRM sebesar 74,192.16

Setiap perusahaan tentu merasa sangat penting dalam melakukan promosi agar produk yang ditawarkan dapat diketahui oleh khalayak banyak. BPRS Di Madura merasa sangat penting melakukan promosi berupa iklan untuk menambah keuntungan perusahaan. Dimana pada saat ini BPRS Di Madura lebih fokus pada promosi yang berupa iklan pada koran, media online, media elektronik dll. BPRS Di Madura dalam membantu meningkatkan penjualan, melakukan berbagai macam promosi melalui iklan. Adapun iklan yang ditayangkan melalui media cetak yaitu koran Radar Madura dan majalah Mata Madura. Sedangkan melalui media elektronik berupa iklan di radio Karimata FM, dan televisi yaitu Madura Chanel dan MJTV.

Berdasarkan penelitian terdahulu di atas, dapat diperoleh gambaran latar belakang tentang pentingnya iklan terhadap keputusan nasabah, dan dapat ditarik kesimpulan tujuan penelitian ini adalah untuk mengetahui efektifitas iklan dengan menggunakan konsep AIDA pada keputusan menjadi nasabah BPRS di Madura.

$\mathrm{H}_{1}$ : Attention berpengaruh terhadap keputusan nasabah.

$\mathrm{H}_{2}$ : Interest berpengaruh terhadap keputusan nasabah.

$\mathrm{H}_{3}$ : Desire berpengaruh terhadap keputusan nasabah.

$\mathrm{H}_{4}$ : Action berpengaruh terhadap keputusan nasabah.

\footnotetext{
13 Sri Wigawati, Perilaku Konsumen Perspektif Ekonomi Islam, vol. 01 No. 01 Juni 2011, diakses tanggal 10 April 2015.

14 Murti Sumarni, Manajemen Pemasaran Bank, Yogyakarta: Liberty, 2011, 235-239.

15Jefri Heridiansyah "Pengaruh Advertising Terhadap Pembentukan Brand Awareness Serta Dampaknya Pada Keputusan Pembelian Produk Kecap Pedas ABC" (jurnal STIE Semarang, vol 4, no 2, edisi juni 2012, 53.

16 Nielsen Djuwandono Hermawan "Efektivitas iklan televisi tokobagus. Com versi "mau jual mobil?" pada masyarakat Surabaya”. (jurnal e-komunikasi, vol 2. no.1 tahun 2014), 11.
} 


\section{METODE PENELITIAN}

Penelitian ini menggunakan pendekatan kuantitatif yakni penelitian dengan menggunakan analisis data statistik atau angka-angka. Sedangkan jenis penelitiannya adalah analisis regresi linear berganda yaitu alat yang digunakan untuk meramalkan nilai pengaruh dua variabel bebas atau lebih terhadap satu variabel terikat untuk membuktikan ada tidaknya hubungan fungsional atau hubungan kausal antara dua atau lebih variabel bebas terhadap variabel terikat. ${ }^{17}$

Penelitian ini adalah termasuk pada model regresi linier berganda. Yaitu untuk mengetahui besarnya pengaruh konsep AIDA (Variabel X/independent variable) terhadap keputusan untuk menjadi nasabah (Variabel Y/dependent variable) di BPRS Di Madura.

Jumlah penelitian ini populasinya tidak diketahui karena itu merupakan hal yang dirahasiakan oleh pihak BPRS Di Madura, oleh sebab itu popolasi yang digunakan adalah seluruh nasabah yang melakukan transaksi dengan BPRS Di Madura, sehingga jumlah sampel yang digunakan paling sedikit 30 sampel atau 10 kali jumlah vareabel. Karena jumlah popolasi atau jumlah nasabah bersifat rahasia, maka peneliti menggunakan tekhnik sampling accidential berjumlah 98 responden. Adapun data dalam penelitian ini didapat dengan menggunakan kuisioner yang diberikan kepada sampel penelitian. Isi kuisioner dibuat berdasarkan pedoman dan kesesuaian pertanyaan dengan isi penelitian.

Penelitian ini menggunakan beberapa indikator pada variabel independen, yaitu: attention, diukur menggunakan pesan yang disampaikan dalam iklan, kepercayaan terhadap produk, serta visualisasi iklan; Interest, diukur menggunakan efektifitas media yang digunakan, persepsi konsumen setelah melihat iklan, dan kejelasan iklan; desire, diukur menggunakan informasi mengenai keunggulan produk, iklan membangkitkan keinginan untuk mengkonsumsi produk, serta iklan menampilkan alasan mengkonsumsi; action, diukur menggunakan keyakinan untuk membeli produk, iklan menggunakan kata-kata yang sopan dan elegan. Sementara itu, indikator untuk mengukur variabel dependen menggunakan pengambilan keputusan, sharing, dan rekomendasi kepada pihak lain.

\section{HASIL DAN PEMBAHASAN}

Uji F (Simultan). Uji $\mathrm{F}$ atau uji simultan bertujuan untuk menguji hipotesis yang menjelaskan "Ada pengaruh yang signifikan antara konsep AIDA terhadap keputusan menjadi nasabah". Jika F hitung $>\mathrm{F}$ tabel dan atau peluangnya $<0.05$ maka dapat disimpulkan bahwa variabel bebas tersebut secara bersama-sama berpengaruh secara signifikan terhadap variabel terikat (Terima Ha). Sebaliknya jika F hitung $>\mathrm{F}$ tabel dan atau peluangnya nilainya di bawah 0,05 maka dapat dikatakan tidak signifikan (Tolak Ha). Adapun hipotesisnya berbunyi: 1) Hipotesis Nol (Ho): Tidak ada pengaruh yang signifikan antara konsep AIDA terhadap keputusan menjadi nasabah BPRS Di Madura. 2) Hipotesis Alternatif (Ha): Ada pengaruh yang signifikan antara antara konsep AIDA terhadap keputusan menjadi nasabah BPRS Di Madura.

\footnotetext{
${ }^{17}$ Sugiyono, Metode Penelitian Kuantitaif Kualitatif $R$ \& D, Bandung: Alfabeta, 2010, 7.
} 
Setelah dilakukan uji $\mathrm{F}$ dengan menggunakan bantuan program SPSS, berikut ini adalah hasil dari uji simultan:

Tabel 1

\begin{tabular}{|c|c|c|c|c|c|c|}
\hline \multicolumn{7}{|c|}{$\begin{array}{c}\text { Hasil Uji F (Uji Signifikansi secara Simultan) } \\
\text { ANOVA }^{\mathrm{b}}\end{array}$} \\
\hline & & Sum of Squares & $\mathrm{Df}$ & Mean Square & $\mathrm{F}$ & Sig. \\
\hline \multirow{3}{*}{1} & Regression & 1213,481 & 4 & 303,370 & 109,113 &, $000^{\mathrm{a}}$ \\
\hline & Residual & 258,571 & 93 & 2,780 & & \\
\hline & Total & 1472,051 & 97 & & & \\
\hline
\end{tabular}

Uji simultan ditunjukkan dengan hasil perhitungan $\mathrm{F}$ test yang menunjukkan nilai $\mathrm{F}$ hitung sebesar 109,113. Nilai F tabel sebesar 2,47 yaitu dengan melihat df1 atau k-1 yakni jumlah variabel dikurangi $1(5-1=4)$ dan df2 $(\mathrm{n}-\mathrm{k})$ yaitu jumlah sampel dikurangi jumlah variabel (98 - $5=93)$.

Nilai $\mathrm{F}$ hitung yang lebih besar dari $\mathrm{F}$ tabel (F hitung: 109,113 > F tabel: 2,47) mengindikasikan bahwa variabel independen yaitu perhatian (attention), tertarik (interest), minat (desire) dan tindakan (action) secara bersama-sama berpengaruh signifikan terhadap keputusan menjadi nasabah BPRS Di Madura dengan tingkat probabilitas 0,000 yang di bawah $\alpha=0,05$. Dengan demikian, dapat disimpulkan bahwa hipotesis alternatif (Ha) yang menyatakan "terdapat pengaruh yang signifikan antara konsep AIDA dengan keputusan nasabah" bisa diterima yang berarti menolak hipotesis nol (Ho) yang berbunyi "tidak terdapat pengaruh yang signifikan antara konsep AIDA dengan keputusan nasabah".

Uji T (parsiall). Uji signifikansi secara parsial dua variabel independen terhadap variabel dependen digunakan untuk mengukur secara terpisah kontribusi yang ditimbulkan dari masing-masing variabel independen terhadap variabel dependen, dengan $\alpha=0,05$ dan

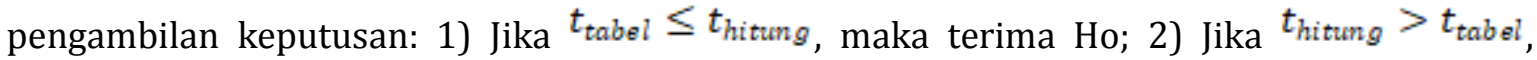
maka tolak Ho; 3) Jika probabilitas > 0.05, maka Ho tidak dapat ditolak (menerima Ho); dan 4) Jika probabilitas < 0.05 , maka Ho ditolak dan menerima Ha. Hasil uji t dapat dilihat pada tabel di bawah ini:

Tabel 2

Hasil Uji t (Uji Signifikansi secara Parsial) Coefficients $^{a}$

\begin{tabular}{ccccccc}
\hline \multirow{2}{*}{ Model } & \multicolumn{2}{c}{$\begin{array}{l}\text { Unstandardized } \\
\text { Coefficients }\end{array}$} & \multicolumn{2}{c}{$\begin{array}{c}\text { Standardized } \\
\text { Coefficients }\end{array}$} & & \\
\cline { 3 - 5 } & & B & Std. Error & Beta & T & Sig. \\
\hline 1 & (Constant) & 8,747 & 1,716 & & 5,099 &, 000 \\
& ATTENTION &, 594 &, 259 &, 212 & 2,297 &, 024 \\
INTEREST &, 688 &, 275 &, 247 & 2,504 &, 014 \\
& DESIRE &, 701 &, 259 &, 236 & 2,706 &, 008 \\
& ACTION &, 755 &, 233 &, 280 & 3,244 &, 002 \\
\hline
\end{tabular}

Empat variabel independen yang dimasukkan dalam regresi, baik perhatian (Attention), tertarik (Interest), minat (Desire) maupun tindakan (Action) memiliki signifikansi berturut-turut $0,024,0,014,0,008,0,002$ di mana masing-masing signifikansi tersebut di bawah $0,05(<0,05)$. Hal ini dapat disimpulkan bahwa keputusan nasabah dipengaruhi oleh perhatian (Attention), tertarik (Interest), minat (Desire) maupun tindakan (Action). 
Selain melihat nilai signifikansinya, dapat pula dilihat dari t hitungnya. Di mana masing-masing $t$ hitung dari setiap variabel memiiki nilai $t$ hitung yang lebih besar dari $t$ tabelnya. Upaya mempermudah $\mathrm{t}$ tabel yaitu dengan melihat $\alpha=0,05$, jumlah sampel dikurangi banyaknya variabel bebas $(98-4=94)$ sehingga diperoleh nilai t tabel sebesar 1,980. Sebagaimana tabel diatas $\mathrm{t}_{\text {hitung }}$ dari variabel $\mathrm{X}_{1}$ (attention) adalah $2,297>1,980$ ( $\mathrm{t}_{\text {hitung }}$ $>t_{\text {tabel}}$ ) yang berarti memiliki pengaruh signifikan terhadap keputusan menjadi nasabah di BPRS Di Madura dan $\mathrm{X}_{2}$ (interest) adalah 2,504 $>1,980$ ( $\mathrm{t}_{\text {hitung }}>\mathrm{t}$ tabel) yang berarti memiliki pengaruh signifikan terhadap keputusan menjadi nasabah di BPRS Di Madura Adapun untuk variabel $\mathrm{X}_{3}$ (desire) adalah 2,706 $>1,980$ ( $\mathrm{t}$ hitung $>\mathrm{t}$ tabel) yang berarti memiliki pengaruh signifikan terhadap keputusan menjadi nasabah BPRS Di Madura dan $\mathrm{X}_{4}$ (action) adalah $3,244>1,980\left(t_{\text {hitung }}>t\right.$ tabel$)$ yang berarti memiliki pengaruh signifikan terhadap keputusan menjadi nasabah BPRS Di Madura.

Sehingga dapat dikatakan ada pengaruh yang signifikan antara perhatian (Attention), tertarik (Interest), minat (Desire) maupun tindakan (Action) secara individu terhadap keputusan menjadi nasabah BPRS Di Madura. Hal ini berarti Ho ditolak dan menerima Ha yaitu ada pengaruh konsep AIDA (aatention, interest, desire, action) terhadap keputusan menjadi nasabah BPRS Di Madura.

Koefisien determinasi berfungsi untuk menjelaskan sejauh mana kemampuan variabel independen (perhatian (attention), tertarik (interest), desire (minat) dan tindakan (action) terhadap variabel dependen (keputusan nasabah).

Tabel 3

Hasil Koefisiensi Determinasi (R2) Model Summaryb

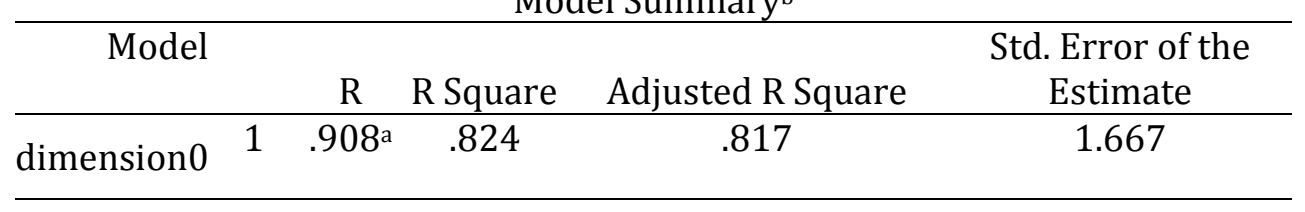

Berdasarkan hasil olahan statistik yang dibantu program SPSS 18.0 for windows menghasilkan $\mathrm{R}$ square sebesar 0,824 yang berarti bahwa variabel independen mampu menjelaskan variabel dependen sebesar $82,4 \%$ sedangkan sisanya $17,6 \%$ dijelaskan variabel lain yang tidak dimasukkan dalam model ini (tidak diteliti).

Hasil uji koefisien determinasi tersebut memberikan makna bahwa variabel independen dalam model ini memberi pengaruh yang cukup besar untuk variabel keputusan menjadi nasabah di mana sebelumnya ada variabel yang belum pernah dimasukkan pada penelitian tentang faktor-faktor keputusan menjadi nasabah di lembaga keuangan yang berbasis syariah. Untuk itu, perlu pengembangan penelitian lebih lanjut terkait dengan topik ini.

Pembuktian hipotesis dalam penelitian ini dilakukan dengan analisis regresi linier berganda untuk meramalkan dan mempediksi besaran variabel tidak bebas yang dipengaruhi oleh variabel bebas. Dari hasil analisis menggunakan program SPSS versi 18, diperoleh hasil sebagai berikut: 
Tabel 4

Hasil Analisis Regresi Linear Berganda

Coefficients ${ }^{a}$

\begin{tabular}{cccccc}
\hline Model & \multicolumn{2}{c}{$\begin{array}{c}\text { Unstandardized } \\
\text { Coefficients }\end{array}$} & $\begin{array}{c}\text { Standardized } \\
\text { Coefficients }\end{array}$ & & \\
\cline { 2 - 4 } & $\mathrm{B}$ & Std. Error & Beta & T & Sig. \\
\hline 1 (Constant) & 8,747 & 1,716 & & 5,099 &, 000 \\
ATTENTION &, 594 &, 259 &, 212 & 2,297 &, 024 \\
INTEREST &, 688 &, 275 &, 247 & 2,504 &, 014 \\
DESIRE &, 701 &, 259 &, 236 & 2,706 &, 008 \\
ACTION &, 755 &, 233 &, 280 & 3,244 &, 002 \\
\hline
\end{tabular}

Berikut ini adalah persamaan dari hasil regresi yang diperoleh:

$$
\begin{aligned}
& \mathrm{Y}=\mathrm{a}+\mathrm{b}_{1} \mathrm{X}_{1}+\mathrm{b}_{2} \mathrm{X}_{2}+\mathrm{b}_{3} \mathrm{X}_{3}+\mathrm{b}_{4} \mathrm{X}_{4} \\
& \mathrm{Y}=8,747+0,594 \mathrm{X}_{1}+0,688 \mathrm{X}_{2}+0,701 \mathrm{X}_{3}+0,755 \mathrm{X}_{4}
\end{aligned}
$$

Hasil persamaan regresi berganda tersebut di atas memberikan pengertian bahwa: 1) Nilai konstanta sebesar 8,747: Hal tersebut dapat diartikan bahwa konsep AIDA (attention, interest, desire, action) memiliki pengaruh yang positif terhadap keputusan menjadi nasabah. Semakin meningkat konsep AIDA (attention, interest, desire, action) semakin meningkat pula keputusan menjadi nasabah; 2) $b_{1}$ (nilai koefisien regresi $X_{1}$ ) sebesar 0,594 mempunyai arti bahwa jika karateristik konsep AIDA tentang attention (X1) pada BPRS tersebut lebih ditingkatkan, sedangkan variabel lain adalah tetap (konstan) maka keputusan nasabah dalam menabung/ mengajukan pembiayaan akan meningkat sebesar 0,$594 ; 3$ ) ${ }^{b_{2}}$ (nilai koefisien regresi $\mathrm{X}_{2}$ ) sebesar 0,688 mempunyai arti bahwa jika konsep AIDA tentang interest (X2) pada BPRS tersebut ditingkatkan, sedangkan variabel lain adalah tetap (konstan) maka keputusan nasabah dalam menabung/mengajukan pembiayaan akan meningkat sebesar 0,$688 ; 4) b_{3}$ (nilai koefisien regresi $\mathrm{X}_{3}$ ) sebesar 0,701 mempunyai arti bahwa jika konsep AIDA tentang desire $\left(\mathrm{X}_{3}\right)$ pada BPRS tersebut ditingkatkan, sedangkan variabel lain adalah tetap (konstan) maka keputusan nasabah dalam menabung/ mengajukan pembiayaan akan meningkat sebesar 0,$701 ; 5)^{b_{4}}$ (nilai koefisien regresi $\mathrm{X}_{4}$ ) sebesar 0,755 mempunyai arti bahwa jika konsep AIDA tentang action $\left(\mathrm{X}_{4}\right)$ pada BPRS tersebut ditingkatkan, sedangkan variabel lain adalah tetap (konstan) maka keputusan nasabah dalam menabung/ mengajukan pembiayaan akan meningkat sebesar 0,755.

Berdasarkan hasil regresi yang didapat menunjukkan faktor tindakan (action) $\left(\mathrm{X}_{4}=\right.$ $0,755)$ merupakan faktor yang paling dominan mempengaruhi keputusan menjadi nasabah, baru kemudian disusul dengan faktor yang lain secara berturut-turut yaitu hasrat (desire)

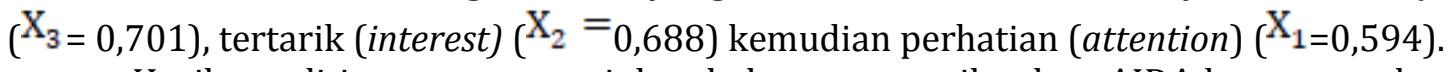

Hasil penelitian yang menunjukan bahwa secara silmultan AIDA berpengaruh secara siknifikan terhadap keputusan nasabah BPRS di Madura. Hal ini dibuktikan berdasarkan koefisien determinasi kemampuan AIDA menjelaskan pengaruhnya terhadap keputusan menjadi nasabah BPRS di Madura sebesar 82,4\% dan 17,6 \% dijelaskan oleh variabel lain yang tidak diteliti. Sedangkan secara parsial AIDA berpengaruh secara signifikan juga terhadap keputusan menjadi nasabah BPRS di Madura dengan tingkat siknifikansi masingmasing $2,4 \%, 1,4 \%, 0,08 \%$ dan 0,02\%. Berdasarkan fakta tersebut konsep AIDA yang paling 
dominan mempengaruhi keputusan menjadi nasabah BPRS di Madura adalah subtansi Action dengan nilai siknifikan 0,02\% dapat dijelaskan sebagai berikut:

Pada tahap Attention, calon nasabah mulai menaruh perhatian kepada suatu produk BPRS. Ini merupakan tahapan penting dalam suatu pemasaran dan telah dilakukan dengan baik oleh bagian Account officer (AO) sebagai marketer di BPRS. Promosi merupakan hal penting dalam pemasaran bahkan sampai dikatakan bahwa promosi merupakan ujung tombak pemasaran. Oleh karena itu, promosi yang dilakukan mampu telah mampu menghipnotis calon nasabah untuk menjadi nasabah bahkan nasabah yang loyal bagi suatu produk BPRS. Di sini hubungan media sosial yang merupakan alat komunikasi yang kini mulai menguasai pasar adalah bahwa media sosial dapat memberikan banyak pilihan dalam mempromosikan suatu produk. Promosi tersebut dilakukan dengan menggunakan tulisan, gambar maupun video yang memiliki daya tarik lebih bagi calon nasabah. Inilah saatnya untuk mengubah calon nasabah menjadi nasabah dengan memancing keingintahuan nasabah akan suatu produk yang di tawarkan BPRS di Madura. Hal ini sesuai dengan konsep pemasaran di mana pemasaran dapat didefinisikan sebagai suatu rangkaian kegiatan termasuk periklanan (Advertising), penjualan (selling), hubungan masyrakat (public relation), promosi penjualan (sales promotion), penentuan harga (pricing), riset pasar (market research) dan sebagainya". ${ }^{18}$ Pengertian pemasaran lainnya menurut Philip Kotler yang dikutip Kasmir adalah "suatu proses sosial dan manajerial dengan mana individu dan kelompok memperoleh apa yang konsumen butuhkan dan inginkan dengan cara menciptakan serta mempertukarkan produk dan nilai dengan pihak lain". ${ }^{19}$ Konsep pemasaran menegaskan bahwa kunci untuk mencapai tujuan organisasi yang ditetapkan adalah perusahaan tersebut harus menjadi lebih efektif dibandingkan para pesaing dalam menciptakan, menyerahkan, dan mengkomunikasikan nilai pelanggan kepada pasar sasaran. ${ }^{20}$

Ada lima konsep dalam pemasaran dimana setiap konsep dapat dijadikan landasan pemasaran oleh masing-masing perusahan, adalah:21: 1) Konsep Produksi; 2) Konsep Produk; 3) Konsep Penjualan; 4) Konsep Pemasaran; 5) Konsep Pemasaran Sosial.

Tujuan pemasaran menurut Kotler dan Keller dalam buku manajemen pemasaran adalah mengetahui dan memahami pelanggan sedemikian rupa, sehingga produk atau jasa itu cocok dengan pelanggan. ${ }^{22}$ Secara umum tujuan pemasaran bank adalah:23 1) Memaksimalkan konsumsi, atau dengan kata lain memudahkan dan merangsang konsumsi, sehingga dapat menarik nasabah untuk membeli produk yang ditawarkan bank secara berulang-ulang; 2) Memaksimalkan kepuasan pelanggan melalui berbagai pelayanan yang diinginkan nasabah. Nasabah yang puas akan menjadi ujung tombak pemasaran selanjutnya, karena kepuasan ini akan ditularkan kebada nasbah lainnya melalui cerita; 3) Memaksimumkan pilihan (ragam produk) dalam arti bank menyediakan berbagai jenis produk sehingga nasabah memiliki beragam pilihan pula; 4) Memaksimumkan mutu hidup dengan memberikan berbagai kemudahan kepada nasabah dan menciptakan iklim yang efisien.

Bauran pemasaran (marketing mix) merupakan kumpulan aktifitas pemasaran yang digunakan untuk melayani pasar sasaran. Marketing mix atau bauran pemasaran sangat

\footnotetext{
18 P R Smith, Great Answers to Tough Marketings Questions. Jakarta: Penerbit Erlangga, 2001, 10.

${ }^{19}$ Kasmir, Pemasaran Bank, Jakarta: Kencana, 2004, 53.

20 M. Nur Rianto Al Arif, Dasar-Dasar Pemasarn Bank Syariah, Bandung: Alfabeta, 2010, 7.

21 Suharno, Yudi Sutarso, Marketing in Practice, Yogyakarta: Graha Ilmu, 2010, 9.

22 Philip Kotler, Kevin Lane Keller, Manajemen Pemasaran, Jakarta: Erlangga 2008.

${ }^{23}$ Kasmir, Pemasaran Bank, Jakarta: Kencana, 2004, 57.
} 
penting diperhatikan pada saat awal pembentukan bisnis. ${ }^{24}$ Hal ini merupakan alasan yang mendasar bagi suatu perusahaan untuk menciptakan suatu produk dan jasa guna memenuhi kebutuhan masyarakat.

Unsur-unsur dari bauran pemasaran (marketing mix) jasa antara lain sebagai berikut:25 1) Produk (Product); 2) Harga (Price); 3) Tempat (Place); 4) Promosi (Promotion); 5) Partisipan (People); 6) Proses (Process); 7) Lingkungan fisik (Physical evidence).

Komunikasi pemasaran atau promosi diselenggarakan oleh bank, bertujuan untuk: ${ }^{26}$, Pertama: Menyampaikan Informasi (Informing). Tujuan ini dilakukan dengan: 1) Menginformasikan kepada calon nasabah atau nasabah mengenai peluncuruk produk atau jasa bank yang baru; 2) Menjelaskan adanya perubahan penggunaan jasa bank; 3) Menginformasikan kepada khlayak perihal semua produk atau jasa bank yang disediakan beserta fasilitas-fasilitasnya; 4) Membangun citra bank secara keseluruhan.

Kedua: Membujuk Nasabah Sasaran (Persuading). Tujuan ini dilakukan dengan: 1) Membentuk pilihan bank; 2) Mengalihkan pilihan kepada bank tertentu; 3) Mendorong calon nasabah untuk mengadakan transaksi saat itu pula; 4) Mengubah persepsi nasabah terhadap atribut produk atau jasa bank

Ketiga: Mengingatkan (Reminding). Tujuan ini dilakukan dengan: 1) Mengingatkan nasabah bahwa produk atau jasa bank yang bersangkutan dibutuhkan dalam waktu dekat; 2) Mengingatkan nasabah mengenai layanan kantor terdekat; 3) Menjaga agar ingatan pertama pembeli jatuh pada produk atau jasa bank.

Selain harus menguasai konsep pemasaran, tugas seorang AO juga harus menguasai konsep periklanan. Periklanan adalah salah satu alat promosi penting yang digunakan oleh perusahaan untuk melancarkan komunikasi terhadap pembeli dan masyarakat yang ditargetkan. Periklanan harus mampu membujuk nasabah supaya nasabah berprilaku sesuai dengan strategi pemasaran perusahaan untuk mendapatkan penjualan dan keuntungan.

Selain dapat memberikan keuntungan, periklanan juga mempunyai kelemahan. Antara lain: 1) Periklanan tidak fleksibel; 2) Informasi terbatas; dan 3) Informasi secara tidak langsung.

Adapun media-media yang digunakan untuk mendukung kegiatan advertising dibagi menjadi tiga bagian utama, antara lain:27 Pertama: Media cetak. Berdasarkan pengertian media cetak, maka media cetak yang digunakan sebagai media untuk kegiatan periklanan terdiri atas: 1) Surat kabar; 2) Majalah; 3) Brosur; 4) Katalog; dan 5) Folder.

Kedua: Media Elektronik. Media elektronik yang digunakan untuk mengiklankan, antara lain: 1) Televisi; dan 2) Radio.

Ketiga: Media luar ruangan (outdoor). Sedangkan tujuan iklan menurut Kotler dan Keller dibagi menjadi empat jenis, yaitu:28 1) Iklan Informatif; 2) Iklan Persuasif (iklan membujuk); 3) Iklan pengingat; dan 4) Iklan Penguat.

Fungsi periklanan, antara lain:29 1) Membantu dalam memperkenalkan produk baru dan kepada siapa atau dimana produk bisa diperoleh; 2) Membantu mempermudah dalam penjualan; 3) Membantu Salesman dalam mengenalkan adanya barang tertentu; 4) Memberikan keterangan penjualan kepada pembeli atau calon-calon pembeli; dan 5) Membantu ekspansi pasar.

\footnotetext{
${ }^{24}$ Rina Rachmawati “Peranan Bauran Pemasaran (Marketing Mix) terhadap Peningkatan Penjualan (Sebuah Kajian terhadap Bisnis Restoran)" (Jurnal Kompetensi Teknik Vol. 2, No. 2, Mei 2011).

25 M. Nur Rianto Al Arif, Dasar-Dasar Pemasarn Bank Syariah, Bandung: Alfabeta, 2010, 14.

26 Murti Sumarni, Manajemen Pemasaran Bank, Yogyakarta: Liberty, 2011, 328-329.

27 Ibid., 138.

28 Philip Kotler \& Kevin Lane Keller, Manajemen Pemasaran, Jakarta: Erlangga, 2008, 203.

${ }^{29}$ Ahmad Subagyo, Marketing In Business, Jakarta: Mitra Wacana Media, 2010, 137.
} 
Pada tahapan interest ini, calon nasabah setelah memperhatikan produk yang di tawarkan BPRS di Madura, beranjak mendekati produk BPRS tersebut tersebut sambil mencari informasi tentang produk tersebut. Nasabah akan mencoba membandingkan dengan produk lain yang sejenis. Di sini calon nasabah mulai mencari apa yang menjadi keunggulan produk yang telah diperhatikan. Di sinilah AO sebagai marketer di BPRS berhasil memasukkan "sugesti" atau pesan-pesan khusus yang semakin membuat calon nasabah menjadi lebih tertarik pada suatu produk: antara lain tentang kelebihan dibanding produk lain, tentang keamanan, tentang keuntungan, tentang layanan dan juga tentang kemudahankemudahan lainnya.

Tugas seorang pemasar, masih belum selesai sampai di tahap interest saja. Selanjutnya, adalah tahap desire yang berarti berniat. Alat pemasaran yang dipilih lewat media sosial akan menjadi lebih potensial dan jauh lebih tepat ketika bisa mendorong keinginan calon nasabah untuk memakai jasa yang dipasarkan oleh BPRS di Madura. Memang persaingan dalam media sosial sangat ketat. Pada tahap ini sebagai calon nasabah, mereka akan menganalisa produk-produk yang sejenis. AO sebagai pemasar di BPRS pada tahap ini telah mampu menonjolkan, meyakinkan calon nasabah bahwa produknyalah yang terbaik untuk di gunakan.

Tahapan terakhir dalam konsep AIDA adalah Action. Tahapan ini merupakan tahapan puncak dan menjadi tolok ukur keberhasilan pengiklanan yang dilakukan. Tahapan ini puncak proses pemasaran dan tentunya menjadi tugas seorang pemasar mencapai puncak keberhasilan ketika calon nasabah berubah menjadi nasabah hal ini ditentukan dengan terjadinya transaksi pembukaan rekening. Saat inilah yang disebut dengan Action dalam konsep AIDA. Tahapan ini juga merupakan batu lonjatan keberhasilan pengiklanan pada waktu-waktu berikutnya. Hal ini bisa terjadi apabila BPRS mampu memberikan fasilitas dan layanan sesuai yang diharapkan oleh nasabah, sehingga nasabah menjadi puas dan akhirnya menjadi loyal. Dan apabila nasabah sudah loyal maka pengiklanan berikutnya dilakukan oleh nasabah tersebut.

\section{PENUTUP}

Berdasarkan hasil penelitian tentang konsep AIDA (attention, interest, desire, action) terhadap keputusan menjadi nasabah BPRS Di Madura, yang telah diuraikan pada bab sebelumnya, maka dapat disimpulkan: 1) Model regresi dari hasil analisis data dengan menggunakan bantuan SPSS versi 18 dapat dikatakan terbebas dari uji asumsi klasik. Hal ini terbukti bahwa, tidak terjadi autokorelasi, heteroskedastisitas, dan data berdistribusi normal. Hasil pengujian hipotesis dengan Uji t menunukan bahwa pada Variabel X1 (Attention) $\mathrm{T}_{\text {hitung }}$ $>\mathrm{T}_{\text {tabel }}(2,297>1,980)$, Variabel X2 (Interest) $\mathrm{T}_{\text {hitung }}>\mathrm{T}_{\text {tabel }}(2,504>1,980)$, Variabel X3 (Desire) $\mathrm{T}_{\text {hitung }}>\mathrm{T}_{\text {tabel }}(2,706>1,980)$, Variabel X4 (Action) $\mathrm{T}_{\text {hitung }}>\mathrm{T}_{\text {tabel }}(3,244>1,980)$ dianggap menerima $\mathrm{H}_{\text {a. }}$. Hal ini menunjukan bahwa Variabel X (konsep AIDA) berpengaruh terhadap keputusan menjadai nasabah (variabel Y); 2 ) Berdasarkan hasil $R$ Square adalah $82,4 \%$. Hal ini berarti sebesar $82,4 \%$ berpengaruh terhadap keputusan menjadi nasabah sedangkan sisanya $17,6 \%$ dipengaruhi variabel lainnya yang tidak diperhitungkan dalam analisis penelitian ini.

\section{DAFTAR PUSTAKA}

Al Arif, M Nur Riyanto. Dasar-Dasar Pemasarn Bank Syariah. Bandung: Alfabeta, 2010. Alma, Buchari. Manajemen Pemasaran dan Pemasaran Jasa. Bandung: Alfabeta, 2011.

Anas, Achmad Tarmidzi, dan Fadllan Fadllan. "Pengaruh Hubungan Berkelanjutan terhadap Kesetiaan Nasabah di BMT NU Cabang Pragaan Kabupaten Sumenep." IQTISHADIA: Jurnal Ekonomi \& Perbankan Syariah 4, no. 1 (2017): 66-81. 
Arikunto, Suharsimi. Prosedur Penelitian, Suatu Pendekatan Praktik. Jakarta: PT Reneka Cipta, 2006.

Arifin, Adyatama. "Pengaruh Periklanan Terhadap Keputusan Pembelian Nasabah Pasta Gigi Pepsodent Di Kota Makassar. Skripsi, Universitas Hasanuddin, Makassar, 2012.

Assauri, Sofyan. Manajemen Pemasaran. Jakarta: Raja Grafindo, 2013.

Departemen Agama RI: Al-Quran dan Terjemahnya Juz 1-30. Surabaya: CV. Pustaka Agung Harapan, 2006.

Djuwitasari, Noor Marriping "Pengaruh Media Periklanan terhadap Perilaku Masyarkat Penabung pada BRI Syariah". Skripsi, UIN Syarif Hidayatullah, Jakarta, 2010.

E, Louis dan David L. Pengantar Bisnis. Jakarta: Erlangga, 2000.

H, Chistopher dan Lauren K. Manajemen Pemasaran Jasa. Jakarta: Indeks, 2005.

Hasan, Iqbal. Analisis Data Penelitian Dengan Statistik, Jakarta : Bumi aksara, 2010.

Heridiansyah, Jefri. Pengaruh Advertising Terhadap Pembentukan Brand Awareness Serta Dampaknya Pada Keputusan Pembelian Produk Kecap Pedas ABC. jurnal STIE Semarang, vol 4, no 2, edisi juni 2012.

Hermawan, Agus. Komunikasi Pemasaran. Jakarta: Erlangga, 2012.

Hermawan, Nielsen Djuwandono "Efektivitas iklan televisi tokobagus. Com versi " mau jual mobil?" pada masyarakat Surabaya". Jurnal e-komunikasi, vol 2. no.1 tahun 2014.

http://www.digilib.uinsby.ac.id.html.

http://www.perbarindo.or.id/salinan-rpojk-BPRS-k.e.pdf.html.

http://www.ojk.go.id

Ismail. Perbankan Syariah. Jakarta: Kencana, 2011.

Johar, Diah Syafita. Pengaruh AIDA (Attention, Interest, Desire, Action) terhadap Efektifitas Iklan online. JAB/Vol. 26 NO. 1 September 2015.

Karim, Adiwarman A. Ekonomi Mikro Islami. Jakarta: PT Raja Grafindo, 2007.

Kasmir. Manajemen Perbankan. Jakarta: Raja Grafindo Persada, 2012.

Kasmir. Pemasaran Bank. Jakarta: Kencana, 2004.

Kasmir. Studi Kelayakan Bisnis. Jakarta: Kencana, 2003.

Kasiram, Moh. Metodologi Penelitian: Refleksi Pengembangan Dan Pemahaman Dan Penguasaan Metodologi Penelitian. Malang: UIN Maliki Press, 2010.

Koncoro, Mudrajat. Metode Kuantitatif. Yogyakarta: Sekolah Tinggi Ilmu Manajemen YKPN, 2011.

L, Chiristopher dan Jochen Wirtz. Pemasaran Jasa Manusia, Tekhnologi, Strategi Perspektif Indonesia. Jakarta: Erlangga, 2010.

Lamb, Hair, McDaniel. Pemasaran. Jakarta: Salemba Empat,2001.

Muhammad. Manajemen Bank Syariah. Yogyakarta: Sekolah Tinggi Ilmu Manajemen YKPN, 2011.

Nuryana, Fatati. Statistik Bisnis Jilid 1. Surabaya: Pena Salsabila, 2013.

Rachmawati, Rina. Peranan Bauran Pemasaran (Marketing Mix) terhadap Peningkatan Penjualan (Sebuah Kajian terhadap Bisnis Restoran. Jurnal Kompetensi Teknik Vol. 2, No. 2, Mei 2011.

Sangiadji, Etta Mamang dan Sopiah. Perilaku Nasabah. Yogyakarta: Andi Offset, 2013.

Setiawan dan Dwi Indah Kusrini. Ekonometrika. Yogyakarta: CV Andi Offset, 2010.

Simamora, Bilson. Riset pemasaran, Falsafah, Teori, dan Aplikasi, Jakarta: PT. Gramedia Pustaka Utama, 2004.

Siregar, Syofyan. Metode Penelitian Kuantitatif: Dilengkapi Dengan Perbandingan Perhitungan Manual dan SPSS. Jakarta: Kencana Prenada Group, 2013.

Smith, P R. Great Answers to Tough Marketings Questions. Jakarta: Penerbit Erlangga, 2001. 
Sochih, Mohammad. Analisis Tingkat Kesehatan Bank Ditinjau Dari Camel (capital, asset quality,management, earning, and liquidity)ntuk mengukur keberhasilan manajemen pada pt bprs margirizki, banguntapan, bantul, yogyakarta. Jurnal pendidikan akuntansi indonesiavol. vi. no. 2, 2008.

Subagyo, Ahmad. Marketing In Business. Jakarta: Mitra Wacana Media, 2010.

Sugiyono. Metode Penelitian Kuantitaif Kualitatif R \& D. Bandung: Alfabeta, 2010.

Suharno dan Yudi Sutarso. Marketing in Practice. Yogyakarta: Graha Ilmu, 2010.

Sujarweni, V. Wiratna dan Poly Endrayanto. Statistik untuk Penelitian. Yogyakarta: Graha Ilmu, 2012.

Sumarni, Murti. Manajemen Pemasaran Bank. Yogyakarta: Liberty, 2011.

Supranto dan Nandan Limakrisna. Perilaku Nasabah \& Strategi Pemasaran. Jakarta: Mira Wacana Media, 2011.

Supriyanto, Achmad Sani dan Masyhuri Machfud. Metodologi Riset Manajemen Sumber Daya Manusia. Malang: UIN Maliki Press, 2010.

Tim Penyusunan Pedoman Penulisan Karya Ilmiah, Pedoman Penulisan Karya Ilmiah. Pamekasan: STAIN Press, 2011.

Wahjono, Sentot Imam. Manajemen Pemasaran Bank. Surabaya: Graha Ilmu, 2009.

Wigawati, Sri. "Perilaku Nasabah Perspektif Ekonomi Islam". vol. 01 No. 01 Juni 2011.

Yuliawan, Eko. Pengaruh Pengetahuan Nasabah Mengenai Perbankan Syariah Terhadap Keputusan Menjadi Nasabah Pada PT. Bank Syariah Cabang Bandung. Wira Ekonomi Mikroskil, vol. 1, No. 01 April 2011. 